\title{
A cave response to environmental changes in the Late Pleistocene: a study of Budimirica Cave sediments, Macedonia
}

\author{
Marjan Temovski ${ }^{1 *}$, Petr Pruner ${ }^{2,3}$, Helena Hercman ${ }^{4}$ and Pavel Bosák 2,3 \\ ${ }^{1}$ Institute for Nuclear Research of the Hungarian Academy of Sciences, Hertelendi Laboratory of Environmental Studies, Bem tér 18/C, H-4026 Debrecen, Hungary; \\ (temovski.marjan@atomki.mta.hu) \\ ${ }^{2}$ Czech Academy of Sciences, Institute of Geology v. v. i., Rozvojová 269, 16500 Praha 6, Czech Republic; (pruner@gli.cas.cz; bosak@gli.cas.cz) \\ ${ }^{3}$ Slovenian Academy of Sciences and Arts, Scientific Research Centre, Institute of Karst Research, Titov trg 2, 6230 Postojna, Slovenia \\ ${ }^{4}$ Polish Academy of Sciences, Institute of Geological Sciences, Twarda 51/55, 00-818 Warszawa, Poland; (hhercman@twarda.pan.pl)
}

doi: $10.4154 / g c .2016 .29$

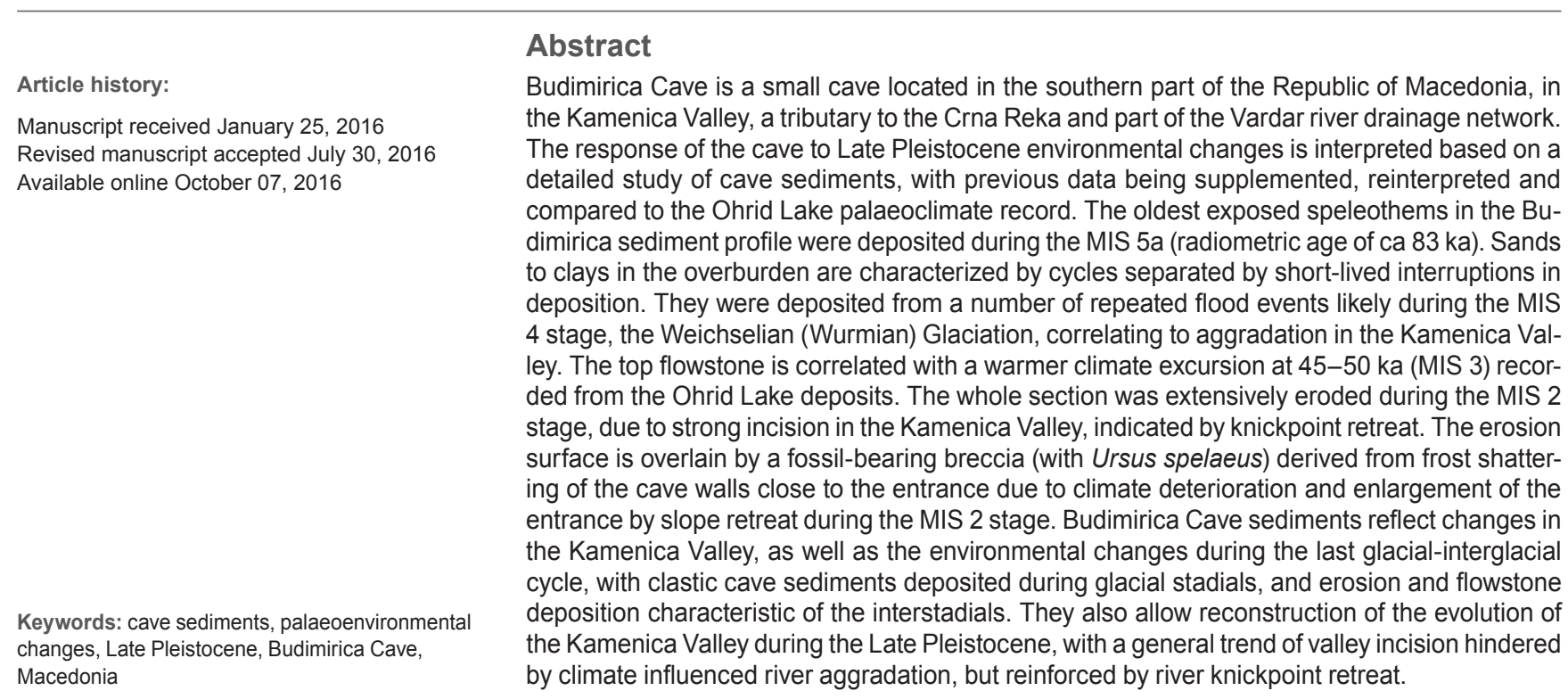

\section{INTRODUCTION}

Caves serve as especially good archives of past environmental information due to both the sensitivity of karst systems to a wide range of environmental changes (i.e. change of recharge dynamics, increase/decrease and character of sediment supply, change of dissolved $\mathrm{CO}_{2}$ content etc.), and great capability to protect the record from erosion as compared with the surface (e. g., HÄUSELMANN et al., 2008, 2015). Most of the recent studies have concentrated on analysis of palaeoenvironmental records from speleothems (e. g., LASCU \& FEINBERG, 2011; or summary in FAIRCHILD \& BAKER, 2012). There exist only rare examples, when speleothems record longer time-span than relatively short climatic optima (like in Pleistocene), but such profiles are mostly pre-Pleistocene in age (BOSÁK et al., 2002; HÄUSELMANN et al., 2015). Clastic cave fill preserves the palaeoenvironmental record and evidence of its changes in similar detail (see summaries a. o. in SASOWSKY \& MYLROIE, 2004; FORD \& WILLIAMS, 2007, or ZUPAN HAJNA et al., 2008) but usually over much longer time-spans than speleothems. The disadvantage of such a record results from complications by the number of post-depositional changes (BULL, 1981) and hiatuses of variable lengths, sediment reworking and redepositon (BOSÁK et. al., 2000; ZUPAN HAJNA et al., 2008, 2010). Moreover, most caves preserve results of only the last depositional cycle, as deposits of previous cycles were usually exhumed due to the general function of cave systems. This can lead to the absence of cave sediments from certain time-periods in whole regions, e.g. Middle Pleistocene sediments are missing in caves of the Bohemian Karst (central Czech Republic; HORÁČEK \& LOŽEK, 1988).

We present an example of palaeoenvironmental analysis of clastic cave sediments belonging to the last depositional cycle of a small cave in the southern parts of the Republic of Macedonia. The interpretation is based on detailed research on the stratigraphy, composition and age of cave sediments. Previous data (TEMOVSKI, 2016) is supplemented, reinterpreted and compared to the palaeoclimate record from the Ohrid Lake sediments. The results provide insight into the effect of Late Pleistocene environmental changes on landscape evolution in the area.

\section{CAVE AND SEDIMENTS}

The Budimirica Cave ( $400 \mathrm{~m}$ a. s. 1.) is located in the right slope of the lower part of the Kamenica Valley (Figs. 1 and 2). The Kamenica River is a tributary to the Crna Reka, the second longest tributary of the Vardar River, the main drainage system of the Republic of Macedonia, draining towards the Aegean Sea. The area is a part of the Vitačevo Plateau (800-1.000 m a.s.l.), composed mostly of Pliocene and Early Pleistocene pyroclastic sediments. They were deposited in lacustrine to fluvial environments of the Tikveš Basin, as part of the Pliocene-Pleistocene Central Macedonian Lake. In places they cover Palaeogene conglomerates (Tertiary Tikveš Basin), and rocks of the Vardar Zone preCenozoic basement: Cretaceous limestones and flysch (Figs. 1 


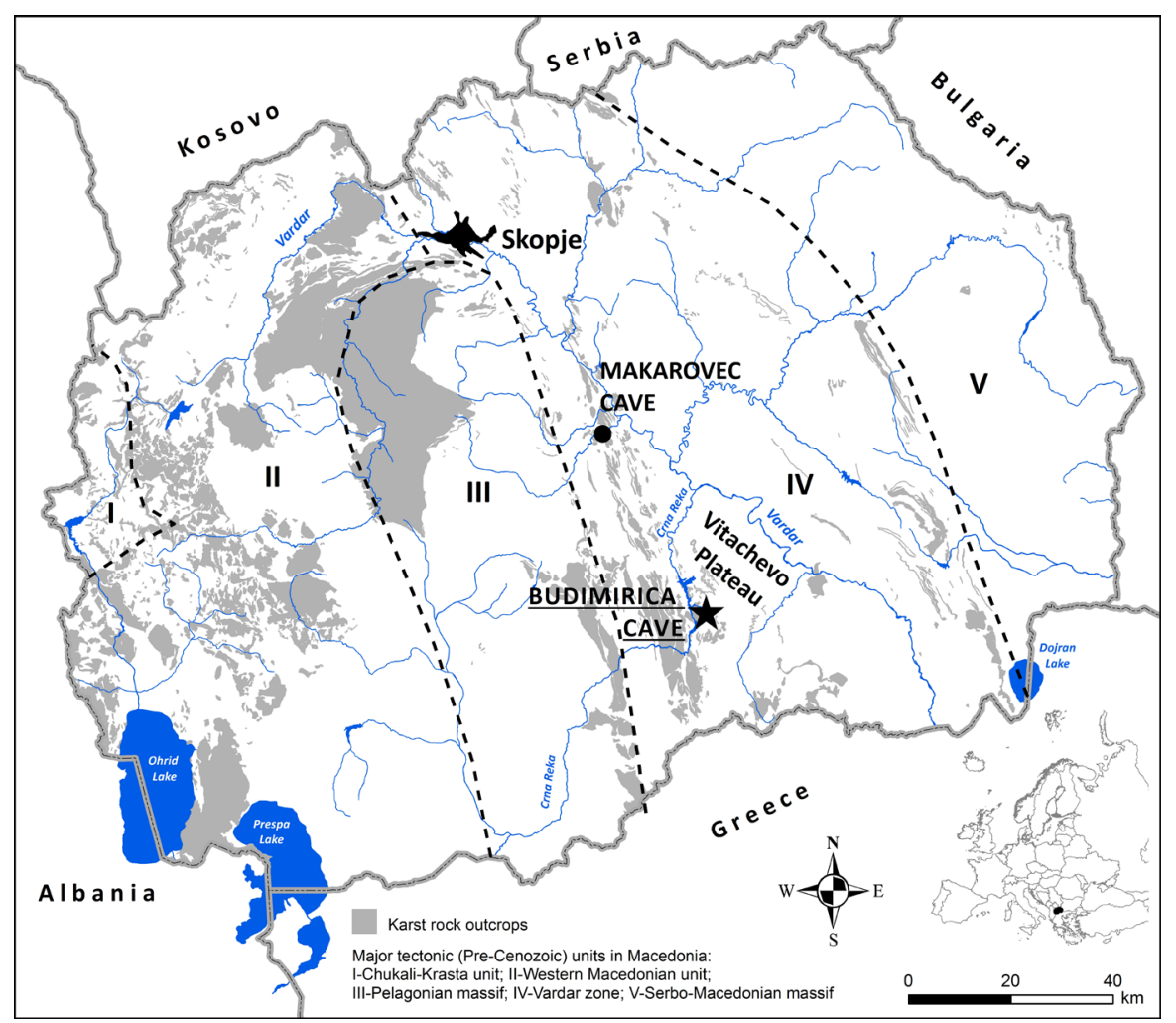

Figure 1. Location of the studied site within the regional geological structure of the Republic of Macedonia. Major geotectonic units are after ARSOVSKI (1997).

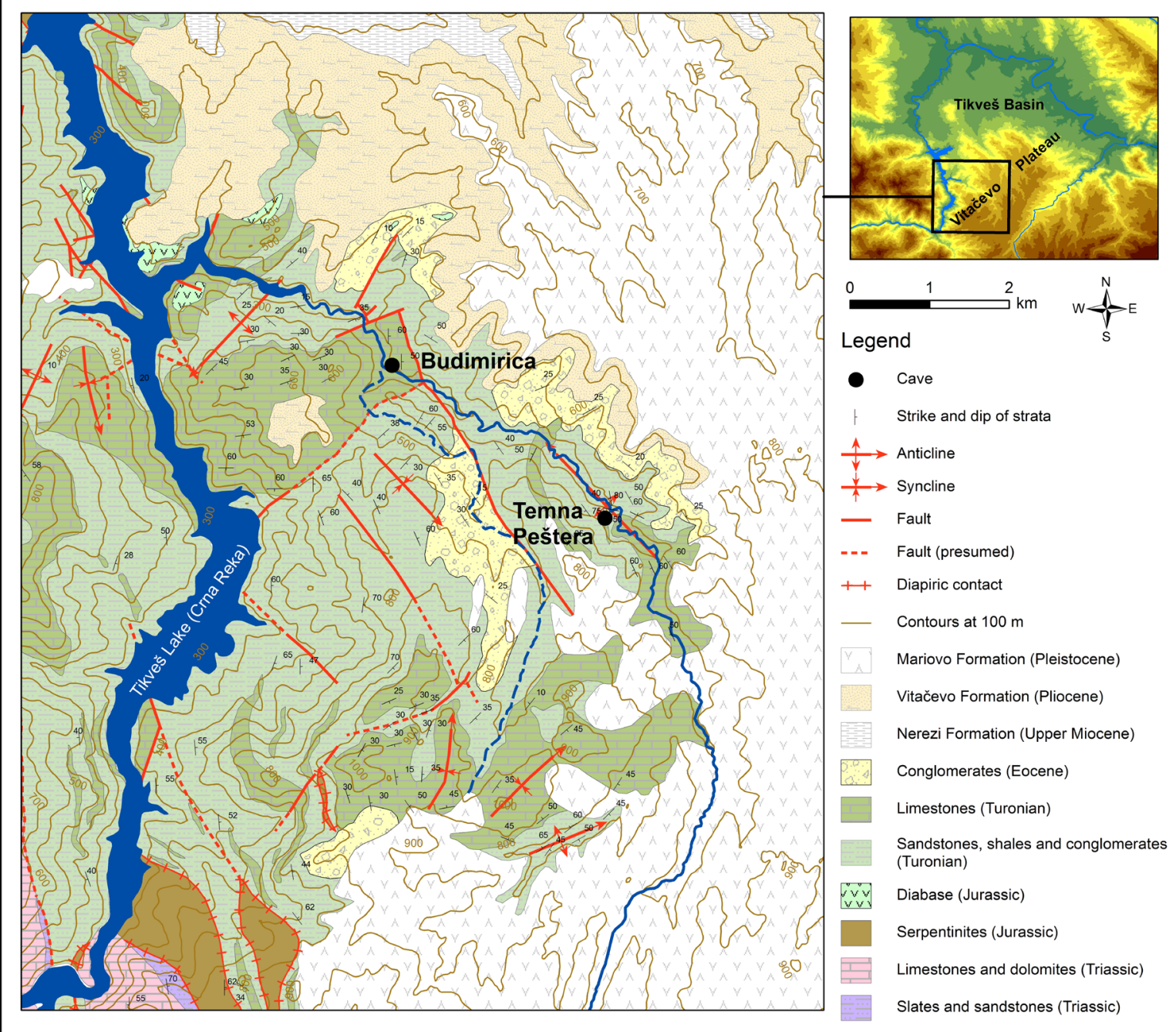

Figure 2. A geological map of the western part of the Vitačevo Plateau showing the location of Budimirica Cave (compiled from DUMURDŽANOV et al., 1976; HRISTOV et al., 1965; RAKIĆEVIĆ et al., 1965; and RAKIĆEVIĆ \& PENDŽERKOVSKI, 1970). 


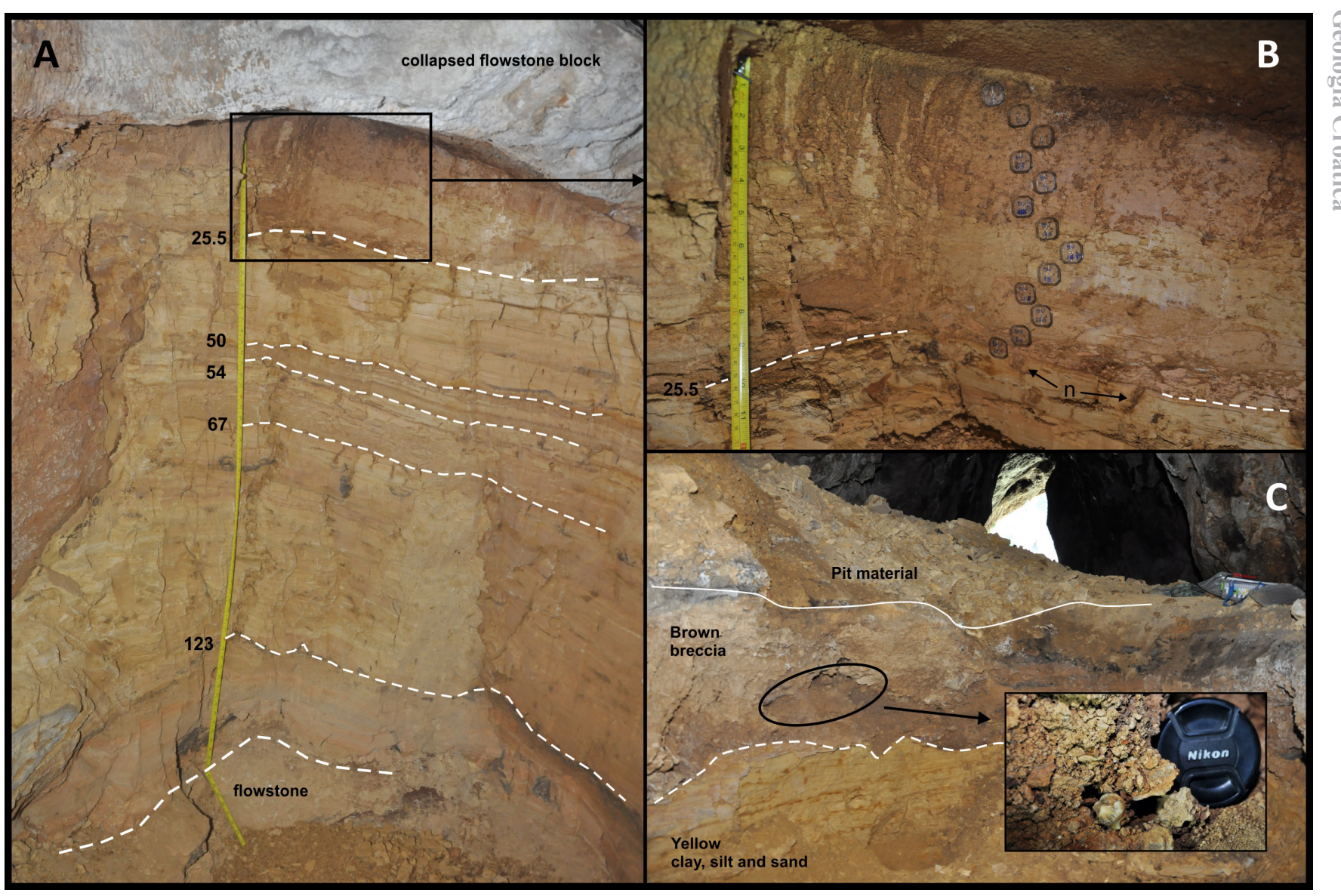

Figure 3. View of the studied sediments in Budimirica Cave: A - The whole profile below the collapsed flowstone block with major unconformities indicated; B - Close-view of the upper part with positions of palaeomagnetic sampling boxes and examples of neptunian dykes (n) along the plane at $25.5 \mathrm{~cm} ; \mathrm{C}-$ Relationship of yellow sediments to the brown breccia deposit, with the black ellipse showing the location of collected fossil samples and close-view photo showing fragments of an Ursus spelaeus molar. Photos by M. Temovski.

and 2; DUMURDŽANOV et al., 1976, 2004). The Central Macedonian Lake was drained probably no later than during the Middle Pleistocene (DUMURDŽANOV et al., 2005) as a result of uplift in the central parts of the Balkan Peninsula and subsidence in the area of Aegean Sea (DUMURDŽANOV et al., 2004). The Kamenica River cut its valley through the pyroclastic deposits down to the pre-Cenozoic basement, uncovering Upper Cretaceous (Turonian) limestones and exposing them to weathering and karstification (TEMOVSKI, 2016).
The Budimirica Cave is $105 \mathrm{~m}$ long and consists of two branching passages with northeastern general direction (MANAKOVIK, 1971). The cave passages formed along the strike direction of Turonian limestones and contain speleogens indicating speleogenesis in phreatic to epiphreatic conditions (TEMOVSKI, 2016). A paragenetic morphology (ceiling channels, pendants) is developed especially above still preserved cave sediments (Fig. 4).

A large excavated pit in yellow- to orange-coloured cave sediments ( $5 \mathrm{~m}$ long, $1.5 \mathrm{~m}$ wide, and $1-1.5 \mathrm{~m}$ deep) is situated in
Figure 4. Detail of the Left Passage with cave morphology, sediment relationships and location of the sampling profile. Modified from TEMOVSKI (2016).

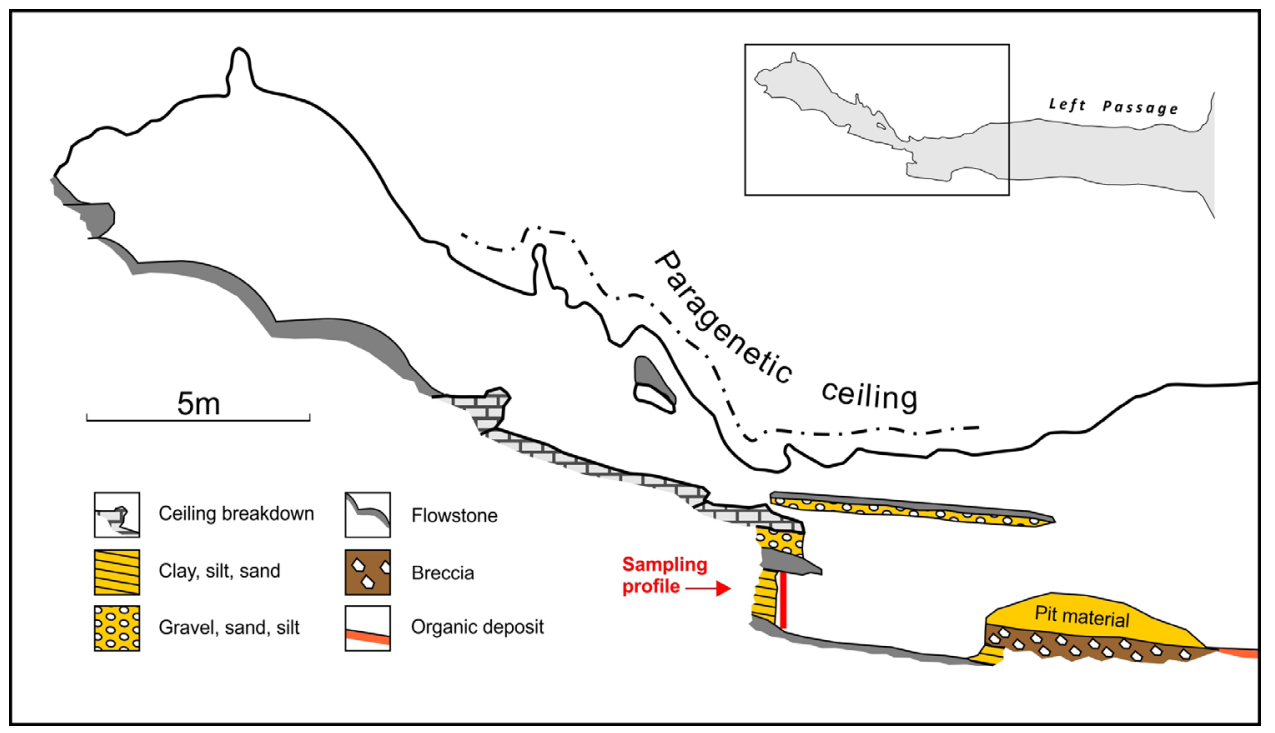




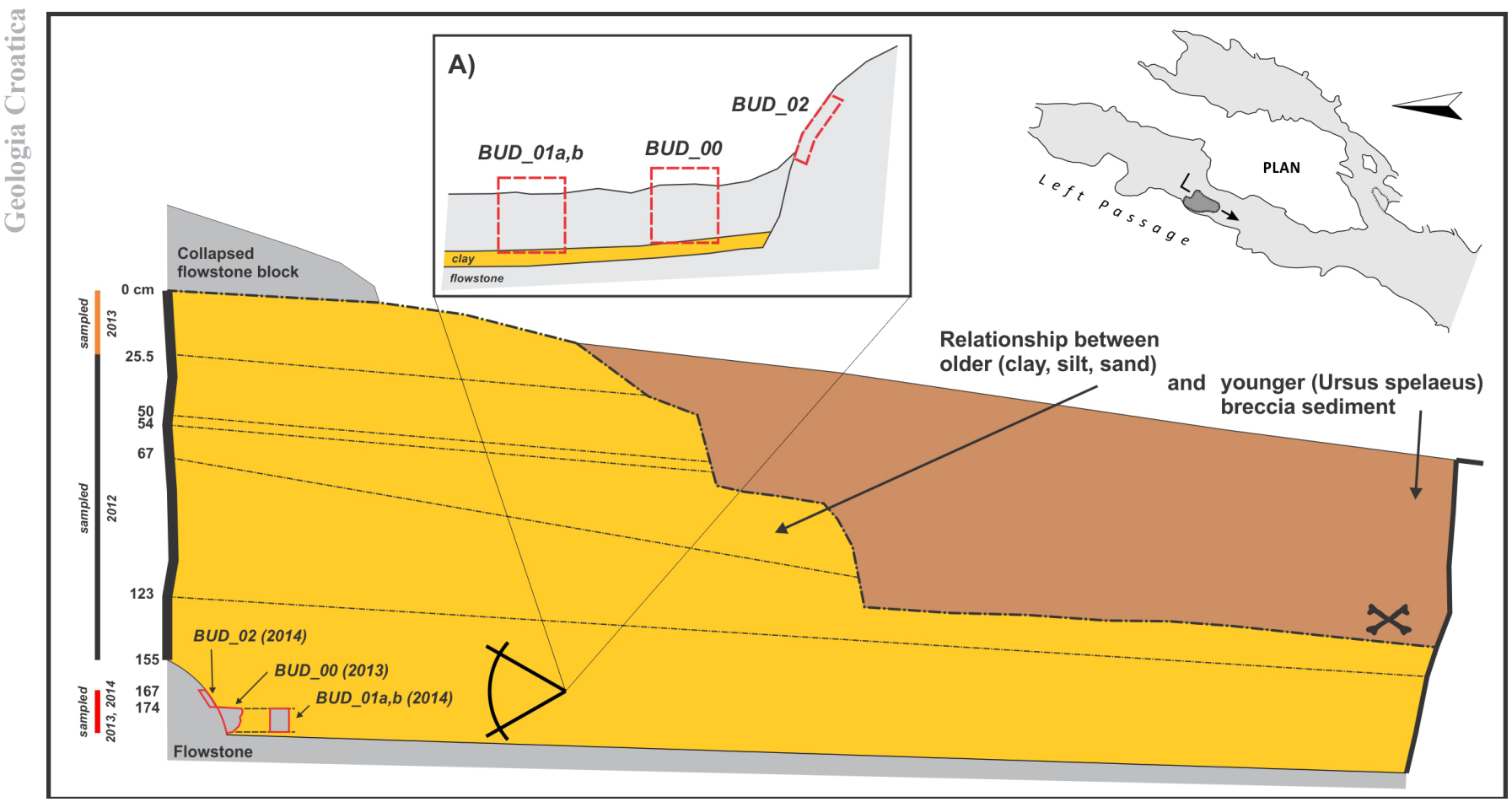

Figure 5. Relationship of sampled sediments to other cave fills and the position of major unconformities (dotted line) in the pit of the Left Passage. Upper illustration (A) shows a frontal view of the lower part of the sampled profile with locations of the flowstone samples. Modified from TEMOVSKI (2016).

the middle part of the Left Passage (Figs. 3 and 4). In the NE part of the pit, the sediment profile starts with flowstone at the bottom, which is followed by ca $1.5 \mathrm{~m}$ thick deposits of silt, clay and sand, covered by a $30 \mathrm{~cm}$ thick collapsed flowstone block (Figs. 4 and 5). Above (and beside) this flowstone block, in one part, the clastic sequence continues with yellowish gravel, sand and silt up to $1 \mathrm{~m}$ thick, covered by flowstone (Figs. 5). This whole section is eroded and covered with brown fossil-bearing breccia in the SW part of the pit (Figs. 3C and 5). The breccia deposits are covered with a $10-15 \mathrm{~cm}$ thick organic deposit close to the cave entrance.

The clastic sequence below the collapsed flowstone block ( 0 $\mathrm{cm})$, down to the bottom flowstone $(155 \mathrm{~cm})$ was studied in detail (TEMOVSKI, 2016). The sequence contains some principle unconformities expressed by dark films (Mn and/or Fe compounds) and desiccation cracks filled by overlying sediments, together with smaller neptunian dykes (Fig.3B). Palaeomagnetic parameters of 56 samples collected from the middle part (between 25.5 and $155 \mathrm{~cm}$ ) showed normal polarized magnetization with a mean palaeomagnetic declination of $2.6^{\circ}$ (TEMOVSKI, 2016).

\section{METHODS AND RESULTS}

\subsection{Palaeomagnetic analysis}

Samples were analyzed at the Institute of Geology of the Czech Academy of Sciences. In total 20 oriented samples from previously non analyzed upper (clastic) and lower (flowstone) parts of the profile (Figs. 4 and 6) were collected for palaeomagnetic dating using the high-resolution sampling methodology described by ZUPAN HAJNA et al. (2008). Palaeomagnetic data for the middle part of the profile was previously published, with 56 measured samples (TEMOVSKI, 2016). Unconsolidated sediments (13 samples) from the upper part of the profile $(0-25.5 \mathrm{~cm})$ were collected in small plastic cubes from individual horizons. Two solid hand samples from the speleothem in the lower part of the profile $(168-181 \mathrm{~cm})$ were cut into 7 cubes $20 \times 20$ × $20 \mathrm{~mm}$. In the laboratory, they were measured on the JR-6A spinner mag- netometer (JELÍNEK, 1966) and/or 2G Superconducting Rock Magnetometer with incorporated AF unit. 17 specimens were demagnetized by the alternating field (AF) procedures, up to the field of $100 \mathrm{mT}$ in 10 to 13 steps and 3 specimens were demagnetized thermally (TD) using the MAVACS apparatus (PŘÍHODA et al., 1989). The AF demagnetization by LDA-3A or SRM demagnetizer including TD demagnetization gave considerably good results. The remanent magnetization (RM) of specimens in their natural state (NRM) is identified by the symbol M. Graphs of normalized values of $\mathrm{M} / \mathrm{M}_{0}=\mathrm{F}(\mathrm{H})$ were constructed for each analyzed specimen. Volume magnetic susceptibility (MS) was measured on a KLY-4 kappa-bridge (JELÍNEK, 1973). Separation of the respective remanent magnetization components was carried out by multi-component Kirschvink analysis (KIRSCHVINK, 1980). The statistics of FISHER (1953) were employed for calculation of mean directions of the pertinent remanence components derived by the multi-component analysis. Both previously published (56 samples) and new data (20 samples) were used for the statistical analyses, with data from four samples excluded where the maximum angular deviation (MAD) was higher than 10 for the multi-component analysis, leaving a total of 72 analyzed samples.

Examples of the TD and AF demagnetization of samples (position 168 and $181 \mathrm{~cm}$ ) with normal $(\mathrm{N})$ palaeomagnetic polarity are presented in Fig. 6. Directions of C-components of remanence with normal palaeomagnetic polarity for the whole profile are given on Fig. 7. Recalculated mean palaeomagnetic directions of $\mathrm{N}$ polarized C-components for the whole profile are $\mathrm{D}=359.0^{\circ}$ and $\mathrm{I}=46.5^{\circ}$.

The sediments from the profile showed only normal polarized magnetization. Mean values of palaeomagnetic directions of the whole profile are documented in Table 1 . The values of palaeomagnetic directions in different segments document palaeosecular variation. The distribution of the NRM and MS in the palaeomagnetic profile (Fig. 8) can indicate changes in deposition as well as the change of external climatic conditions. 


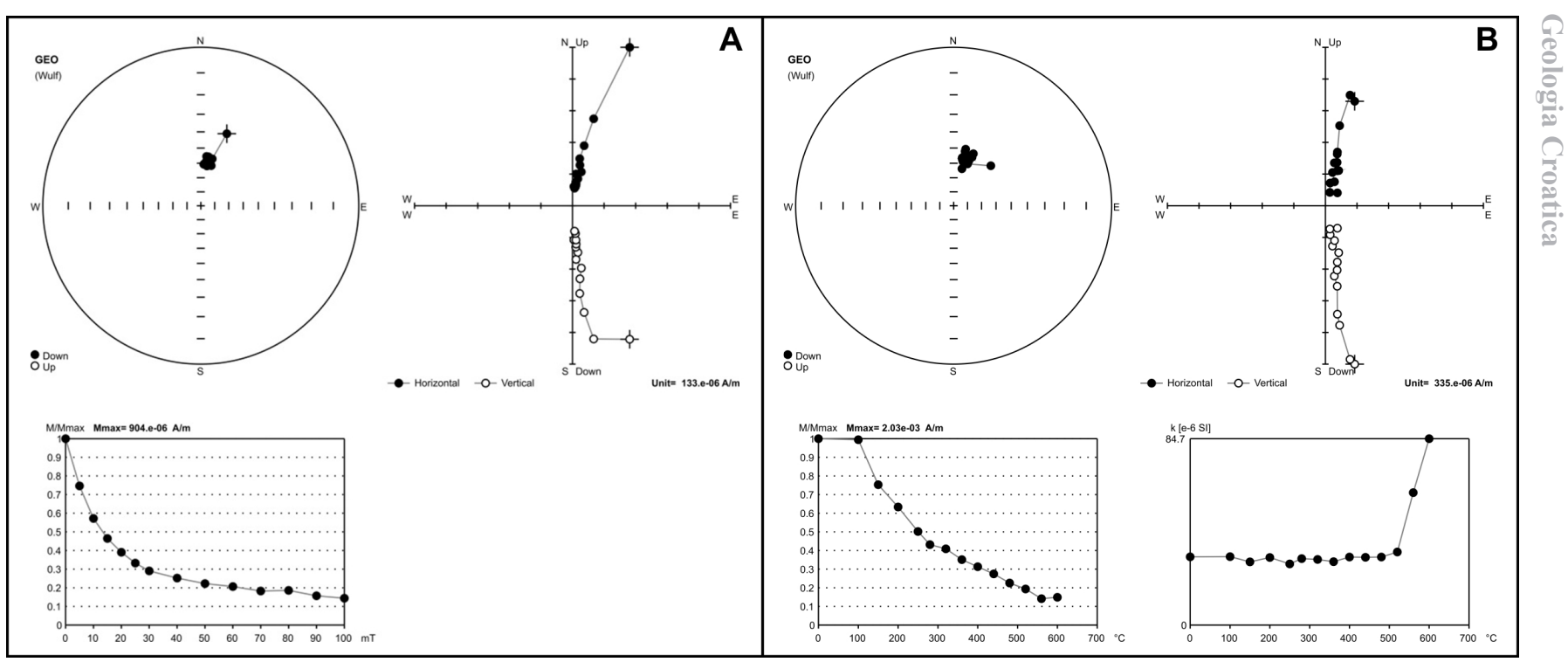

Figure 6. Example (A) of the AF demagnetization (position $181 \mathrm{~cm}$ ) and (B) the TD demagnetization (position $168 \mathrm{~cm}$ ) of samples with normal palaeomagnetic polarity from the Budimirica Cave. Upper left - a stereographic projection of the natural remanent magnetization of a sample in the natural state (cross section) and after progressive AF and/or TD demagnetization; upper right - the Zijderveld diagram: solid circles represent projection on the horizontal plane (XY), open circles represent projections on the north-south vertical plane (XZ); lower left - a graph of normalized values of the remanent magnetic moments versus demagnetizing fields: $\mathrm{M}$ - modulus of the remanent magnetic moment of a sample subjected to AF and/or TD demagnetization. Lower right - a graph of the normalized values of volume magnetic susceptibility versus thermal demagnetizing fields: $k$ - value of volume magnetic susceptibility of a sample subjected to TD demagnetization.

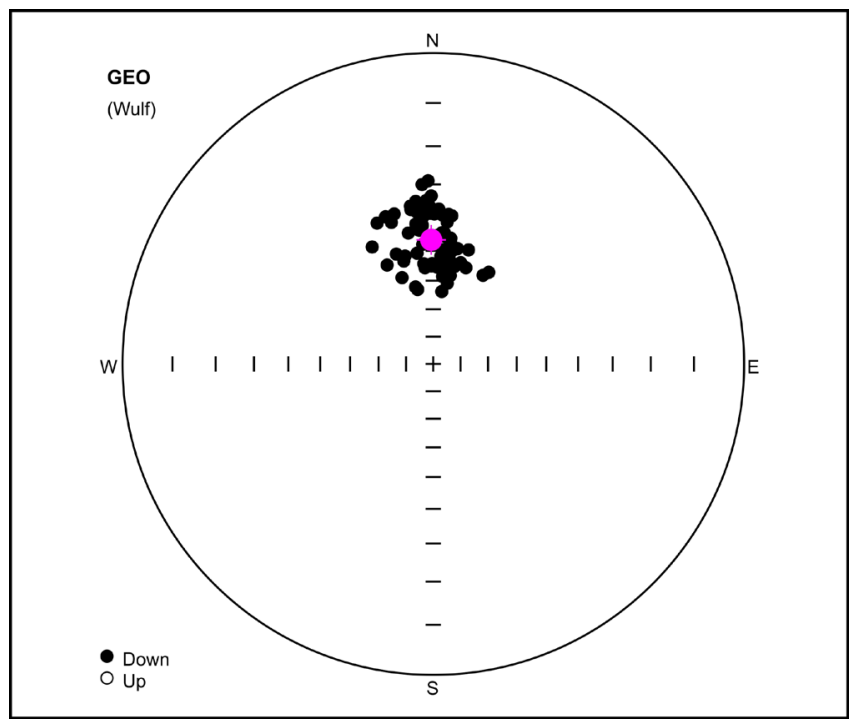

Figure 7. Directions of C-components of remanence with normal palaeomagnetic polarity for the whole profile in Budimirica Cave. Stereographic projection, full (open) small circles represent projection onto the lower (upper) hemisphere. The mean directions calculated according to FISHER (1953) are marked by a small cross across a circle, the confidence circle at the $95 \%$ probability level is circumscribed about the mean direction.

\subsection{Radiometric dating (U-series)}

The $\mathrm{Th} / \mathrm{U}$ (U-series) dating was performed in the Geochronology Laboratory, Institute of Geological Sciences, Polish Academy of Sciences in Warsaw (analysts Helena Hercman). Standard chemical procedures for uranium and thorium separation from carbonate samples were used (IVANOVICH \& HARMON, 1992). The activity was measured by $\alpha$-spectrometry, using an ORTEC OCTETE PC. Spectral analyses and age calculations were made with URANOTHOR 2.5 software, which is the standard software in the Geochronology Laboratory in Warsaw (GORKA \& HERCMAN, 2002). The quoted errors are one standard deviation. The bottom flowstone deposit (sample
Table 1. Mean palaeomagnetic directions for the whole profile in Budimirica Cave, recalculated using data from this study and TEMOVSKI (2016).

\begin{tabular}{lccccccc}
\hline \multirow{8}{*}{$\begin{array}{l}\text { Budimirica } \\
\text { Cave }\end{array}$} & Polarity & \multicolumn{3}{c}{$\begin{array}{c}\text { Mean palaeomagnetic } \\
\text { directions }\end{array}$} & $\begin{array}{c}\alpha_{95} \\
{\left[{ }^{\circ}\right]}\end{array}$ & $k$ & $\mathrm{~N}$ \\
\cline { 2 - 6 } & $\mathrm{N}$ & 359.0 & 46.51 & 2.42 & 51.12 & 72
\end{tabular}

Explanations: $D, I$ - declination and inclination of the NRM; $a_{95}$ - semi-vertical angle of the cone of confidence calculated according to FISCHER (1953) at the $95 \%$ probability level; $\mathrm{k}$ - precision parameter; $\mathrm{N}$ - number of analysed samples.

Table 2. U-series dating results.

\begin{tabular}{lllllcc}
\hline Sample & Lab. No. & ${ }^{238} \mathrm{U}[\mathrm{ppm}]$ & ${ }^{234} \mathrm{U} /{ }^{238} \mathrm{U}$ & ${ }^{230} \mathrm{Th} /{ }^{234} \mathrm{U}$ & ${ }^{230} \mathrm{Th} /{ }^{232} \mathrm{Th}$ & Age [ka] \\
\hline BUD_00 & W 3152 & $0.0331 \pm 0.003$ & $1.09 \pm 0.13$ & $0.54 \pm 0.07$ & 43 & +16 \\
& & & & & -14 \\
\hline
\end{tabular}

BUD_00) was dated to $83(+16 /-14)$ ka (Fig. 5, Tab. 2). Dating of sample BUD_02 (which belongs to a stratigraphically older layer) was not successful due to strong detrital Th contamination.

\subsection{Geomorphological analyses of the Kamenica Valley}

A longitudinal profile of the Kamenica River was constructed from 1:25000 topographic maps (VOJNOGEOGRAFSKI INSTITUT, 1973) using the Global Mapper v.16 and Grapher v.11, and was analyzed to identify changes in channel slope, with geological information along the profile obtained from 1:25000 geological maps (GEOLOŠKI ZAVOD - SKOPJE, unpublished).

Field observations in the Kamenica Valley near Budimirica Cave registered the remnant of a river terrace opposite the cave at $80 \mathrm{~m}$ relative elevation. Combined field and topographic map observations registered three river terraces in the middle part of the Kamenica Valley, nearby Temna Peštera - Dragožel, with relative elevations of $30 \mathrm{~m}, 60 \mathrm{~m}$, and $80 \mathrm{~m}$ above the Kamenica River. Their position shows their relationship to caves in both localities (TEMOVSKI, 2016). 


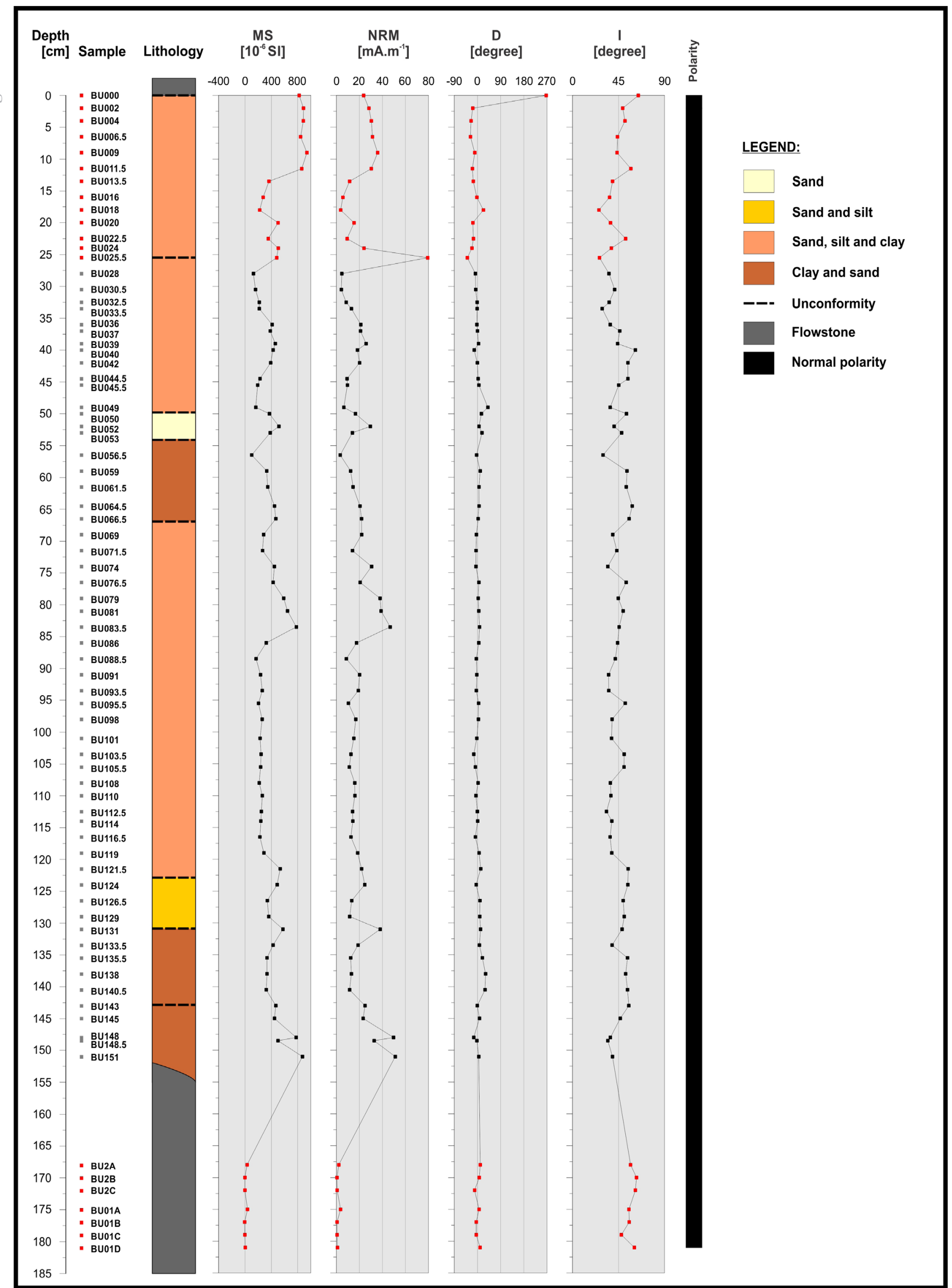

Figure 8. Basic magnetic properties for the whole profile in the Budimirica Cave. Data in red is from this study, others after TEMOVSKI (2016). Note that flowstone samples BU01 (A-D) are younger than samples BU2 (A-C), and are found at lower position as a results of the slope of the flowstone deposit (see Fig. 5 for clear view of relationship). 


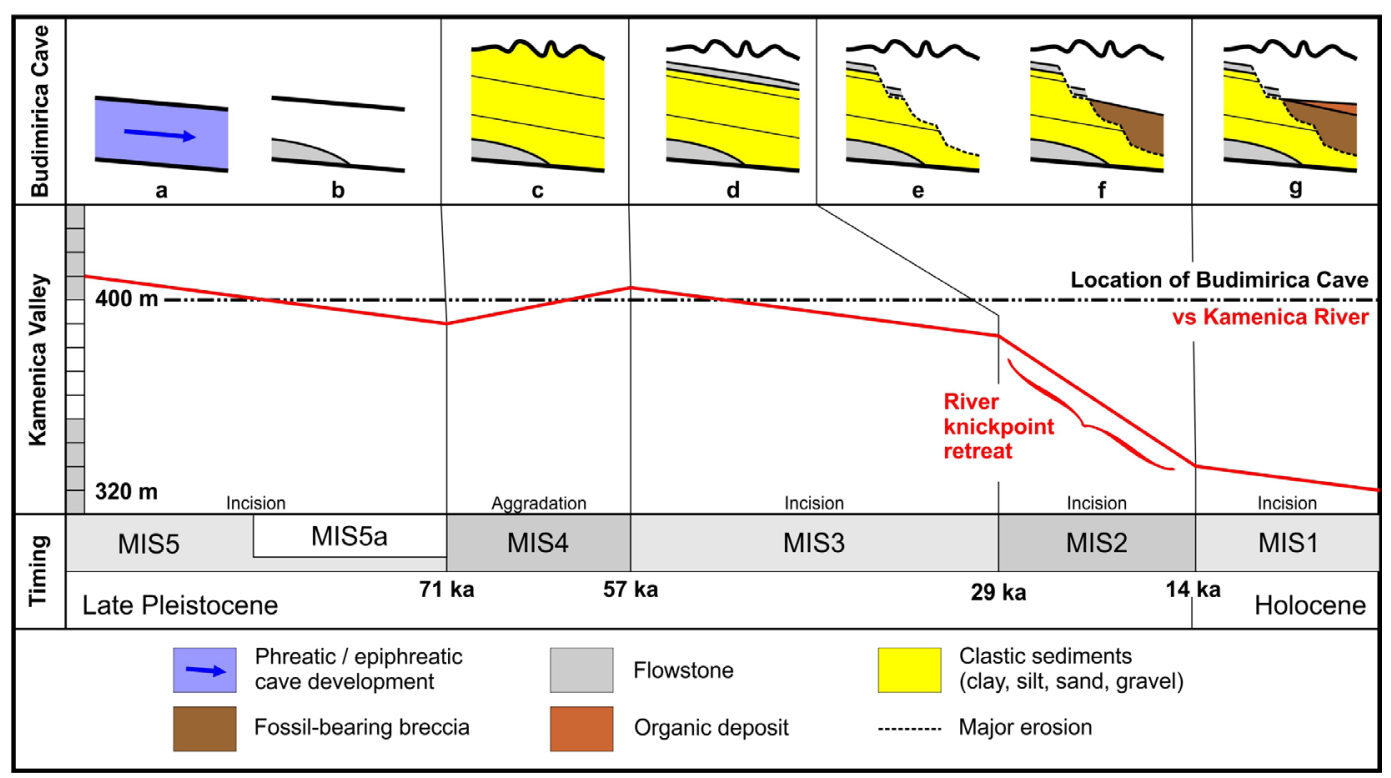

Figure 9. Schematic illustration of the evolution of Budimirica Cave deposits and their relationship to the changes in the Kamenica Valley with their interpreted ages. See text for explanation. Red line represents changes in elevation of Kamenica River talweg.

\subsection{Ohrid Lake palaeoenvironmental record}

Detailed studies of sediments from Ohrid Lake (Fig. 1), from several cores at different locations, have been undertaken recently, with published data providing palaeoenvironmental information dating back to the Middle Pleistocene (LACEY et al., 2016 and references therein).

To compare with the environmental changes registered within the Budimirica Cave sediments we used Late Pleistocene palaeoclimate data derived from a study of a multi-proxy record from the sediments of JO2004-1 core, from the southwestern part of Ohrid Lake (BELMECHERI et al., 2010; LEZINE et al., 2010).

\section{DISCUSSION}

\subsection{Cave response to Late Pleistocene environmental changes}

Passages of the Budimirica Cave formed along the strike direction of the Turonian limestones in phreatic to epiphreatic environments (Fig. 9a). The age of speleogenesis cannot be precisely stated, but it is possible that it was connected with the period before the incision of the Kamenica River Valley, indicated by small cave remnant on the opposite side of the valley (the Karši Budimirica Cave; TEMOVSKI, 2016). Paragenetic speleogens (ceiling channels, pendants) are developed in many places, especially above the preserved cave sediments, indicating the upward development of passages after sediment aggradation in the vadose evolution stages of the cave (TEMOVSKI, 2016).

The flowstones on the passage floor were deposited in vadose conditions (Fig. 9b). A radiometric age of ca 83 ka suggests an origin during the interstadial of the Marine Isotopic Stage (MIS) 5a. This period was characterized by a warm and wet climate, supporting an increase in vegetation cover and carbon dioxide production according to the Ohrid Lake record (BELMECHERI et al., 2010; LEZINE et al., 2010), although having less favourable conditions compared to the Last (Eemian) Interglacial (MIS 5e). The dated flowstone layer (sample BUD_00) represents the upper layer below the clastic deposits, and it is covering an older layer of flowstone separated with a thin clay layer. Although the dating of the older layer was unsuccessful, the stratigraphy (Fig. 5) indicates that the lower layer (BUD_02) was likely deposited in older interstadials during MIS 5, with clay deposits deposited during the stadial period.

The basal flowstone is covered with clastic deposits (up to the collapsed flowstone block) composed of two different lithostratigraphic segments divided by a distinct unconformity at 123 $\mathrm{cm}$ : a sandy one in the lower part and a generally fine-grained one above (TEMOVSKI, 2016). The sandy character of the lower segment indicates the higher energy of the flowing water than in later overlying cycles. Upper segment sediments are composed of well-sorted fine-grained sediments, and are a typical example of internal cave facies lithology (sensu KUKLA \& LOŽEK, 1958). Sediments were sorted when transported through the shallow phreatic/epiphreatic siphonal cave system, where the coarser-grained components were deposited closer to ponor(s). The cave fill represents the results of repeating floods in a relatively calm but not completely stagnant sedimentary environment (slackwater deposits sensu BOSCH \&WHITE, 2004), i. e. originating from waning floodwaters or other pulsed flow ( $c f$. FORD \& WILLIAMS, 2007). Such a sedimentary environment has been known from number of caves in the north Dinaric Classical Karst and adjacent areas (e.g., ZUPAN HAJNA et al., 2008, 2010).

The profile consists only of a few single flood events (cycles) limited by unconformities with short-lasting hiatuses (compaction and dewatering, desiccation, small erosions). Each flood partly eroded older sediments and deposited its load. The depositional and post-depositional textures (e.g. water-escape structures) indicate the very rapid depositional rates, which is supported by uncentered secular variation detected from the calculation of mean values of palaeomagnetic directions in the upper profile segment. The cyclic character resulted from a fluctuating hydrological regime in the cave and reflected environmental changes influencing the recharge regime and base level position in the Kamenica Valley. Individual layers, which also differ in their magnetic properties (MS and NRM values), reacted to changes in the catchment area (change of source rocks, continuing erosion of weathering profiles) and external climatic changes (cf. e. g., SROUBEK et al., 2001). 
The studied sediments contain minerals that are also typical for the volcanic and volcaniclastic source rocks and their weathering products - especially sanidine, smectite (motmorillonite) and kaolinite (TEMOVSKI, 2016). According to the kaolinite content and absence of macroscopically visible sedimentary particles derived from volcanic and volcaniclastic rocks, the source material was composed of re-deposited materials derived from well-developed weathering profile(s).

Only normal polarized magnetization is typical for the studied sediments. Mean values of palaeomagnetic directions calculated from the whole profile are close to the present magnetic field - the value of mean palaeomagnetic declination of $359^{\circ}$ is close to the present magnetic declination for Macedonia with a value of $2.7^{\circ}$. Sediments are not older than $780 \mathrm{ka}$ (Brunhes chron) as also indicated by the radiometric age of the underlying flowstone. The distribution of the MS on the studied profile can indicate changes in deposition as well as the change of external climatic conditions.

Considering that the clastic sequence follows the MIS 5a flowstone, it is assumed to be deposited during the MIS 4 stadial (Fig. 9c). Lacustrine deposits of that age from the Ohrid Lake (BELMECHERI et al., 2010; LEZINE et al., 2010) record a generally cold and dry climate. The Budimirica fill indicates changing climatic conditions with several relatively short-lasting but quite massive floods reflecting most probably highly fluctuating periodic precipitation rates.

The deposits are eroded below the paragenetic ceiling and covered with the top flowstone, indicating another change of the depositional environment, towards a rather slower low-volume water flow (Fig. 9d). The top flowstone was likely deposited during the MIS 3 interstadial, as it follows the MIS 4 clastic sequence and is followed by strong erosion overlain with MIS 2 deposits. The Ohrid Lake sediments (BELMECHERI et al., 2009, 2010) registered the MIS 3 warmer and wetter climate excursion at $45-50 \mathrm{ka}$.

The whole flowstone-clastic sediments-flowstone sequence was then deeply eroded and the cave fill was exhumed extensively (Fig. 9e), likely by the invasion(s) of allogenic waters triggered by the strong incision of the Kamenica Valley, continuing water table fall, and change of environmental conditions during the MIS 2 stage.

The deep erosion of both clastic sediments and the topmost flowstone was followed by the deposition of fossil-bearing brec- cia close to the cave entrance (Fig. 9f). Angular limestone fragments in the breccia deposit represent the products of frost shattering of cave walls especially at and near the cave entrance. This can be a result of both climate deterioration and enlargement of the cave entrance due to slope retreat in the valley, which correlates well with the strong incision of the Kamenica Valley indicated by the previous erosion of cave sediments. Among several other bones, two teeth belong to Ursus spelaeus (R. GAREVSKI, pers. comm., 2012; J. WAGNER, pers. comm., 2013), which can be compared with late Weichselian (Wurmian 2/3 and Wurmian 3) bear remains from the Makarovec Cave located in the Babuna Valley in a neighbouring basin to the north of the studied cave (Fig. 1); GAREVSKI (1969) and GAREVSKI \& MALEZ (1984). Therefore the breccia can be attributed to the latest cold period of the Weichselian glaciation (MIS 2). Ohrid Lake sediments indicate unstable environmental conditions during this period with a fluctuation of precipitation and temperature (LEZINE et al., 2010).

The top organogenic deposits are likely due to recent (Holocene) pasturage and represent sheep and/or cow coprolites (Fig. 9g).

\subsection{Valley incision and aggradation}

The clastic deposition (as well as associated paragenetic morphology) in Budimirica Cave correlates with the remnant of a river terrace located in the gorge-like Kamenica Valley opposite the cave (Fig. 10), at an elevation of $395 \mathrm{~m}$ (80 m above the present Kamenica River) indicating river aggradation. It was previously considered (TEMOVSKI, 2016) to belong to the same aggradation registered further upstream by a terrace in the middle part of the Kamenica Valley (and the clastic sediments in the Temna Peštera - Dragožel cave), with the terrace (and the cave) located at the same relative elevation (Figs. 2 and 10), $80 \mathrm{~m}$ above the present Kamenica River. Preliminary U-series dating of the flowstone covering the clastic sequence in Temna Peštera - Dragožel gave an age older than $350 \mathrm{ka}$ (H. HERCMAN, per comm., 2015), dating the terrace as much older than the one at Budimirica Cave, thus indicating stronger erosion and/or uplift in the lower part of the Kamenica Valley.

The river aggradation corresponding to the terrace at $\mathrm{Bu}$ dimirica Cave is attributed to the MIS 4 glacial stadial, with a cold climate affecting vegetation cover and soil activity, which

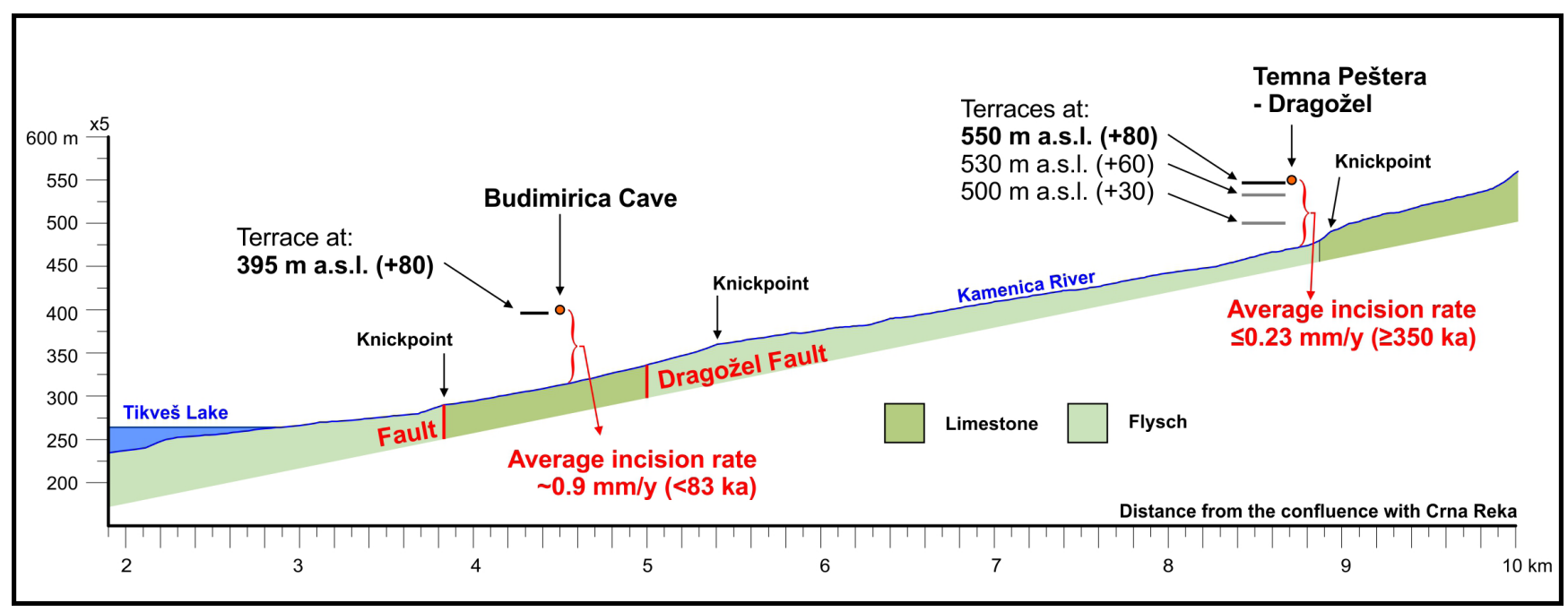

Figure 10. Longitudinal profile along the lower and middle part of the Kamenica Valley, showing locations of caves, river terraces, knickpoint positions and inferred valley incision rates. 
increases the erosion potential in the basin. This was likely reinforced by the seasonality of precipitation and runoff, thus increasing sediment productivity and forcing aggradation of the river valley. Such conditions (enhanced erosion) were also registered in the drainage basin of the Ohrid Lake during the Late Pleistocene cold stadials (LEZINE et al., 2010).

The longitudinal profile along the Kamenica Valley shows several knickpoints (sharp changes in channel slope; Fig. 10). One is located a little upstream from Temna Peštera-Dragožel, at the contact of the limestone and flysch, and is fixed (structurally and hydrologically), with the upstream karst system discharging along the contact and providing an increase in river potential for erosion. Another (fixed) one is downstream from the Budimirica Cave, along the fault at the contact of the flysch and limestone, and may also indicate uplift of the limestone block. A third knickpoint can be noticed a little upstream from the limestone block where the Budimirica Cave is developed. The location of this knickpoint (not at the contact of limestone and flysch, but further upstream, in the flysch) and the higher river gradient in the limestone block indicates headward retreat of the knickpoint, and thus stronger downstream erosion, which could be responsible for the strong erosion registered in the Budimirica Cave during the MIS 2.

Such strong erosion is also indicated by the average incision rate of the Kamenica Valley based on the radiometric ages of the flowstone deposits in the Budimirica Cave and Temna Peštera Dragožel (Fig. 10). The bottom flowstone in the Budimirica Cave sediment profile (dated at ca $83 \mathrm{ka}$ ) was deposited when the water table was a few metres lower than the cave $(\sim 395 \mathrm{~m})$, and thus with relative elevation of $80 \mathrm{~m}$ above the Kamenica River, this gives an average incision rate of $\sim 0.96 \mathrm{~mm}^{-1}$ for the last $83 \mathrm{ka}$. In the middle part of the Kamenica Valley, at Temna Peštera Dragožel, the upper flowstone (covering the clastic deposits), which is at least $350 \mathrm{ka}$ old (and follows previous aggradation), points to (a maximum) average incision rate of $0.23 \mathrm{~mm} \cdot \mathrm{y}^{-1}$. This value is almost five times smaller than that below the Budimirica Cave, although it represents a longer period (which could also include longer periods of incision paucity and/or aggradations). However, the incision in the lower part is still quite high, and correlates well with the strong erosion registered in the Budimirica Cave sediments.

\section{CONCLUSION}

Cave deposits preserved in the Budimirica Cave reflect the response of the cave system to the environmental changes in the drainage basin. The Budimirica Cave is part of a contact karst system receiving both allogenic and autogenic recharge. Incision of the Kamenica Valley lowered the water table and allowed deposition of flowstone under vadose conditions during the MIS 5a. Flowstone deposits were covered by allogenic clastic sediments, originating from the weathered profiles of pyroclastic sediments of the Plio-Pleistocene Vitačevo and Mariovo Formations. They were deposited in the cave in several floods as a result of the increase of sediment supply and a base level rise due to aggradation in the Kamenica Valley in the MIS 4, which also forced upward paragenetic development of the cave. Continuing incision of the Kamenica Valley allowed erosion of the upper part of the clastic sequence and deposition of the upper flowstone deposits during the MIS 3, followed by strong erosion during MIS 2 as a result of fast incision triggered by river knickpoint retreat. This influenced enlargement of the entrance by slope retreat and deposition of fossil bearing breccia due to frost shattering during the cold sta- dial. Recent Holocene input is restricted to human pasturage influence with deposition of organogenic deposits.

The interpreted evolution of the cave deposits indicates that flowstone deposition corresponds to glacial interstadials (MIS 5a and MIS 3), and clastic sediment deposition corresponds to glacial stadials (MIS 4 and MIS 2). Cold periods affect vegetation cover and soil activity, which together with the seasonality of precipitation increases erosion in the basin, and the increase of sediment productivity forces aggradation in the valley, which also affected the cave development. The warm and wet climate of the interstadials, supports vegetation productivity and soil development, which reduces erosion and sediment supply, and allows speleothem deposition in the cave.

The general trend of incision in the Kamenica valley was hindered due to climate induced aggradation during the MIS 4, but continued during MIS 3 and was reinforced by knickpoint retreat during MIS 2. This change also affected the cave, with incision lowering the water table and influencing erosion of the cave sediments.

Dating of the changes in the Kamenica Valley registered in cave sediments from the Budimirica Cave gives information about valley incision rates along the Kamenica Valley, with high incision rates in the lower part of the Kamenica Valley being in agreement with the inferred incision rates of Quaternary valleys in the mountainous areas of Macedonia (MILEVSKI \& KOLČAKOVSKI, 2012).

\section{ACKNOWLEDGEMENT}

We would like to thank Darko NEDANOSKI for helping with the sampling. The palaeomagnetic analysis (Jiří PETRÁČEK and Kristýna ČÍŽKOVÁ), evaluation and preparation of the paper were carried out in the Institute of Geology of the CAS, v. v. i. and supported by the Plan of the Institutional Financing No. RVO67985831 (2012-2017). Part of the preparation of the paper was carried out at the Hertelendi Laboratory of Environmental Studies (MTA Atomki), supported by MTA Postdoctoral Fellowship Programme, No. PP-030/2015 (2015-2017). We also wish to thank the reviewers for their constructive comments.

\section{REFERENCES}

ARSOVSKI, M. (1997): Tektonika na Makedonija.- Rudarsko-geološki fakultet, Štip, $360 \mathrm{p}$

BELMECHERI, S., NAMIOTKO, T., ROBERT, C., VON GRAFENSTEIN, U. \& DANIELOPOL, D.L. (2009): Climate controlled ostracods preservation in Lake Ohrid (Albania, Macedonia).- Palaeogeography, Palaeoclimatology, Palaeoecology, 277, 236-245. doi:10.1016/j.palaeo.2009.04.013

BELMECHERI, S., VON GRAFENSTEIN, U., ANDERSEN, N., EYMARD-BORDON, A., RÉGNIER, D., GRENIER, CH. \& LÉZINE, A.-M. (2010): Ostracodbased isotope record from Lake Ohrid (Balkan Peninsula) over the last $140 \mathrm{ka}$.Quaternary Science Reviews, 29, 3894-3904. doi:10.1016/j.quascirev.2010.09.011

BOSÁK, P., HERCMAN, H., MIHEVC, A. \& PRUNER, P. (2002): High resolution magnetostratigraphy of speleothems from Snežna Jama, Kamniške-Savinja Alps, Slovenia.-Acta carsologica, 31/3, 15-32.

BOSÁK, P., PRUNER, P., MIHEVC, A. \& ZUPAN HAJNA, N. (2000): Magnetostratigraphy and unconformities in cave sediments: case study from the Classical Karst, SW Slovenia.- Geologos, 5, 13-30.

BOSCH, R.F. \& WHITE, W.B. (2004): Lithofacies and transport of clastic sediments in karstic aquifer-- In: SASOWSKI, I.D. \& MYLROIE, J. (eds.): Studies of Cave Sediments. Physical and Chemical Records of Paleoclimate. Kluwer Academic/ Plenum Publishers, 1-22.

BULL, P.A. (1981): Some fine-grained sedimentation phenomena in caves.- Earth Surface Processes and Landforms, 6/1, 11-22.

DUMURDŽANOV, N., HRISTOV, S., PAVLOVSKI, B. \& IVANOVA, V. (1976): Explanatory notes for the General Geological map of Vitolište and Kajmakčalan, 1:100000 (in Macedonian).- Federal Geological Survey, Belgrade, 61 p. 
DUMURDŽANOV, N., SERAFIMOVSKI, T. \& BURCHFIEL, B.C. (2004): Evolution of the Neogene-Pleistocene Basins of Macedonia.- Geological Society of America. Digital Map and Chart Series, 1, 1-20.

DUMURDŽANOV, N., SERAFIMOVSKI, T. \& BURCHFIEL, B.C. (2005): Cenozoic tectonics of Macedonia and its relation to the South Balkan extensional regime.Geosphere, 1, 1-22.

FAIRCHILD, I.J. \& BAKER, A. (2012): Speleothem Science. From Process to Past Environments.- Wiley-Blackwell, Chichester, 432 p.

FISHER, R. (1953): Dispersion on a sphere.- Proceedings of the Royal Society, A 217, 295-305.

FORD, D.C. \& WILLIAMS, P.W. (2007): Karst Hydrology and Geomorphology.- Wiley, Chichester, $562 \mathrm{p}$.

GAREVSKI, R. (1969): Stratigrafsko i paleontološko značenje na pleistocenskata fauna od pešterata Makarovec vo klisurata na rekata Babuna vo okolinata na Titov Veles.- Prirodonaučen Muzej Skopje, 6, 1-70.

GAREVSKI, R. \& MALEZ, M. (1984): Kvartarna fauna vertebrate iz spiljskih naslaga Makedonije.- Deveti jugoslovenski speleološki kongres, Zagreb, 667-680.

GEOLOŠKI ZAVOD-SKOPJE: Geological Map 1:25000, sheets: Begnište, Bošava, Pološko, Šškovo (unpublished).

GORKA, P. \& HERCMAN, H. (2002): URANOTHOR v. 2.5. Delphi Code of calculation program and user guide: MS.- Archive of Quaternary Geology Department, Institute of Geological Sciences, PAS, Warsaw, 65 p.

HÄUSELMANN, PH., LAURITZEN, S-E., JEANNIN, P-Y \& MONBARON, M. (2008): Glacier advances during the last $400 \mathrm{ka}$ as evidenced in St. Beatus Caves (BE, Switzerland).- Quaternary International, 189, 173-189.

HÄUSELMANN, PH., MIHEVC, A., PRUNER, P., HORÁČEK, I., ČERMÁK, S., HERCMAN, H., SAHY, D., FIEBIG, M., ZUPAN HAJNA, N. \& BOSÁK, P. (2015): Snežna jama (Slovenia): interdisciplinary dating of cave sediments and implication for landscape evolution.- Geomorphology, 247, 10-24. doi: 10.1016/ j.geomorph. 2014.12.034

HORÁČEK, I. \& LOŽEK, V. (1988): Palaeozoology and the Mid-European Quaternary past: scope of the approach and selected results.- Rozpravy Československé akademie věd, řada matematických a prírodních věd, 98/4, 1-102.

HRISTOV, S., KARAJOVANOVIĆ, M. \& STRAČKOV, M. (1965): Explanatory notes for the General Geological Map of Kavadarci, 1:100000.-Federal Geological Survey, Belgrade, 62 p. (in Macedonian)

IVANOVICH, M. \& HARMON, R.S. (1992): Uranium series disequilibrium. Applications to environmental problems. 2nd Ed.- Clarendon, Oxford, 910 p.

JELÍNEK, V. (1966): A high sensitivity spinner magnetometer-- Studia Geophysica et Geodaetica, 10, 58-78.

JELÍNEK, V. (1973): Precision A.C. bridge set for measuring magnetic susceptibility and its anisotropy.- Studia Geophysica et Geodaetica, 17, 36-48.

KIRSCHVINK, J.L. (1980): The least-squares line and plane and the analysis of palaeomagnetic data.- Geophysical Journal of the Royal Astronomical Society, 62, 699-718.

KUKLA, J. \& LOŽEK, V. (1958): K problematice výzkumu jeskynních výplní.-Československý kras, 11, 19-59.
LACEY, J.H., LENG, M.J., FRANCKE, A., SLOANE, H.K., MILODOWSKI, A., VOGEL, H., BAUMGARTEN, H., ZANCHETTA, G. \& WAGNER, B. (2016): Northern Mediterranean climate since the Middle Pleistocene: a 637 ka stable isotope record from Lake Ohrid (Albania/Macedonia).- Biogeosciences, 13, 1801-1820. doi:10.5194/bg-13-1801-2016

LASCU, I. \& FEINBERG, J.M. (2011): Speleothem magnetism.- Quaternary Science Reviews, 30/23-24, 3306-3320.

LÉZINE, A.-M., VON GRAFENSTEIN, U., ANDERSEN, N., BELMECHERI, S., BORDON, A., CARON, B., CAZET, J.-P., ERLENKEUSER, H., FOUACHE, E., GRENIER, C., HUNTSMAN-MAPILA, P., HUREAU-MAZAUDIER, D., MANELLI, D., MAZAUD, A., ROBERT, C., SULPIZIO, R., TIERCELIN, J.-J., ZANCHETTA, G. \& ZEQOLLARI, Z. (2010): Lake Ohrid, Albania, provides an exceptional multi-proxy record of environmental changes during the last glacialinterglacial cycle.- Palaeogeography, Palaeoclimatology, Palaeoecology, 287, 116-127. doi: 10.1016/j.palaeo.2010.01.016

MANAKOVIK, D. (1971): Podzemni karstni oblici vo porečieto na Kamenica so karsna hidrografija.--Godišen Zbornik, Geografski Institut, Skopje, 19, 41-59. (in Macedonian)

MILEVSKI, I. \& KOLČAKOVSKI, D. (2012): Recent Landform Evolution in Macedonia.- In: LOCZY, D., STANKOVIANSKY, M. \& KOTARBA, A. (eds.): Recent Landform Evolution. The Carpatho-Balkan-Dinaric Region.- Springer, 413-442.

PŘÍHODA, K., KRS, M., PEŠINA, B. \& BLÁHA, J. (1989): MAVACS - a new system creating a nonmagnetic environment for palaeomagnetic studies.- Cuadernos de Geologica Ibérica, 12, 223-250.

RAKIĆEVIĆ, T. \& PENDŽERKOVSKI, J. (1970): Explanatory notes for the General Geological map of Kožuf, 1:100000.- Federal Geological Survey, Belgrade, 47 p. (in Macedonian)

RAKIĆEVIĆ, T., STOJANOV, R. \& ARSOVSKI, M. (1965): Explanatory notes for the General Geological Map of Prilep 1:100000.- Federal Geological Survey, Belgrade, $65 \mathrm{p}$. (in Macedonian)

SASOWSKI, I.D. \& MYLROIE, J. (2004): Studies of Cave Sediments. Physical and Chemical Records of Paleoclimate.- Kluwer Academic / Plenum Publishers, $329 \mathrm{p}$.

SROUBEK, P., DIEHL, J.F., KADLEC, J. \& VALOCH, K. (2001): A Late Pleistocene palaeoclimate record based on mineral magnetic properties of the entrance facies sediments of Kulna Cave, Czech Republic.- Geophysical Journal International, $147,247-262$

TEMOVSKI, M. (2016): Evolution of karst in the lower part of Crna Reka river basin.Springer, $265 \mathrm{p}$.

VOJNOGEOGRAFSKI INSTITUT (1973): Topographic Maps 1:25000, sheets Prilep and Demir Kapija, Beograd.

ZUPAN HAJNA, N., MIHEVC, A., PRUNER, P. \& BOSÁK, P. (2008): Palaeomagnetism and Magnetostratigraphy of Karst Sediments in Slovenia.-Založba ZRC SAZU, Postojna-Ljubljana, Carsologica, 8, 266 p.

ZUPAN HAJNA, N., MIHEVC, A., PRUNER, P. \& BOSÁK, P. (2010): Palaeomagnetic research on karst sediments in Slovenia.- International Journal of Speleology, $39 / 2,47-60$. 